\title{
Efficiency and responsiveness of using phosphorus and molecular diversity among soybean cultivars
}

\author{
Marcos Morais Soares ${ }^{1} \oplus$, Tuneo Sediyama ${ }^{\circledR}$ and Éder Matsuo ${ }^{3, *}(\mathbb{0}$ \\ ${ }^{1}$ Centro Universitário Luterano de Palmas, Departamento de Agronomia, CEP 77.019-900, Palmas, TO, Brazil. ${ }^{2}$ Universidade \\ Federal de Viçosa, Departamento de Agronomia, Campus Universitário, CEP 36.570-900, Viçosa, MG, Brazil. ${ }^{3}$ Universidade Federal \\ de Viçosa - Campus de Rio Paranaíba, Instituto de Ciências Exatas e Tecnológicas, Laboratório de Bioestatística, Rodovia MG 230, \\ Km 7, Caixa Postal 22, CEP 38.810-000, Rio Paranaiba, MG, Brazil. *Corresponding author, E-mail: edermatsuo@ufv.br
}

\begin{abstract}
Plants use two strategies for their development under nutrient limiting conditions that are the efficiency increase of usage and acquisition. In this situation, the use of efficient genotypes for acquisition and utilization of phosphorus $(\mathrm{P})$ may be a complementary solution to minimize possible problems related to this nutrient in Brazilian soils. Thus, this study aimed to verify the efficiency, response, and cultivar molecular diversity concerning the phosphorus availability variations. The experiment was carried out in a greenhouse using twelve soybean cultivars, such as W 711; MSoy 7211; Anta 82; TMG 1176; MSoy 7908; TMG 132; Valiosa; MSoy 8766; BRS 271; MSoy 9144; Tracajá; and Candeia. The seeds of each cultivar were sown on soil with two doses: 30 and $300 \mathrm{mg} P$ per soil $\mathrm{kg}$. The efficiency indexes, response to $\mathrm{P}$, and molecular analyzes were evaluated. The most efficient cultivars in the use of $P$ and responsive to the increase of P were TMG 1176, TMG 132, Valiosa, and MSoy 9144.
\end{abstract}

Keywords: Glycine max, absorption, microsatellites, Molecular markers, soybean yield, soybean breeding.

\section{INTRODUCTION}

Soybean (Glycine max (L.) Merrill) have played a leading role in grain production increase in the Brazil. Part of this success is resulted from the soybean breeding programs developed by Brazilian researchers of institutes and universities (Bortolotto et al., 2015; Camargos, Campos, Alves, Ferreira, \& Matsuo, 2019; Harada, Gonçalves, Kiihl, \& Destro, 2015).

Plants use two strategies for their development under limiting conditions of phosphorus ( $P$ ), the efficiency increase of usage and acquisition. The efficiency increase of usage involves reducing the growth rate, growth increase per absorbed $\mathrm{P}$ unit, modifications in carbon metabolism by alternative routes, and alternative respiratory routes. On the other hand, the greater acquisition includes the production and excretion of phosphatases, organic acid exudation, greater root growth with change of the root system architecture, expansion of the root surface with development of fine roots, and increase of gene expression for inorganic P conveyors (Lambers, Shane, Cramer, Pearse, \& Veneklaas, 2006; Rausch \& Bucher 2002; Shenoy and Kalagudi, 2005).

Sahrawat and Sika (2002) report the efficiency of $P$ recovery in irrigated rice, ranging from 5 to $11 \%$. Novais \& Smyth (1999) report values for soybean, ranging from 2 to $16 \%$. According to Lynch \& Ho (2005), the involved processes in the $P$ acquisition by plants are the diffusion and replenishment of the soil solution with nutrient and the elongation of the root system.

About the genetic control of these processes, the characteristics related to $P$ absorption are usually polygenic (Clarkson \& Hawkesford, 1993), as well as the efficiency of P utilization in the production of dry matter; and both dominant as additive effects have shown to be important (Fu, Peterson, \& Morrison, 2007; Wang, Guan, Zhangxiong, Chang and Qiu 2006).

The use of efficient genotypes for acquisition and utilization of $\mathrm{P}$ can be a supplementary solution to minimize potential problems associated with $\mathrm{P}$ on Brazilian soils, because it increases productivity, reduces production costs, and the use of natural reserves of this nutrient in the environmental context. In addition, it is a strategic objective for plant breeding programs for mineral stress (Fritsche-Neto \& Borém, 2012; Soares, Silva, Oliveira, Sekita, \& Dias, 2014).

Molecular markers has been used in several studies on soybeans, such as:

- to evaluate the diversity of phenotypic and molecular traits in soybean cultivars launched in forty years 
of breeding (Oda et al., 2015);

- to evaluate the genetic diversity of soybean in the summer and winter using agromorphological traits and molecular markers (Silva et al., 2017);

- to study the genetic diversity of soybean lines developed by the breeding program of the Federal University of Tocantins, seeking the production of biodiesel in the state (Oliveira, Furmigare, \& Peluzio, 2019);

- to investigate polymorphism among 30 soybean genotypes using SSR markers (Kujane, Sedibe, \& Mofokeng, 2019);

- to investigate the genetics of high seed protein in AC Proteus using molecular genetic approaches by studying the high seed protein content loci in bi-parental populations and in AC Proteus-derived high protein cultivars (Samanfar et al., 2019);

- to study the genetic analysis and fine mapping of phosphorus efficiency locus 1 (PE1) in soybean (Yang et al., 2019);

- to evaluate the effects of two single nucleotide polymorphisms (SNPs) over soybean SPC in a single and multi-environment (MET) approach (Bernardeli et al., 2020);

- to analyze the genetic diversity and inter-relationship, according to the release year of developed soybean varieties in Korea using SSR markers (Hwang, Gwak, Sung, \& Kim, 2020); and

- to evaluated the P efficiency by using the photosynthesisrelated traits in 219 diverse soybean accessions across three different environments and dissected the underlying mechanism using a high-resolution genome-wide association study (GWAS) (Yang et al., 2020).

Thus, we aimed to verify the efficiency, response, and molecular diversity of cultivars concerning the phosphorus availability variations.

\section{MATERIALS AND METHODS}

This study was carried out in two phases. The first phase consisted of the genotype characterization for efficient use of $P$, and the second phase was the molecular level's characterization.

First stage - It was carried out under greenhouse conditions in Viçosa City, Minas Gerais State (MG), Brazil. Thirty days before the experimental installation (before seeding), a soil chemical and physical analysis was carried out. Then, the correction of soil acidity was performed. The fertilization with $P$, potassium, sulfur, and micronutrients was made according to the soil analysis. Particularly, in the case of $P$ fertilization, two doses of 30 ( $\mathrm{P} 1$ dose) and 300 (P2 dose) $\mathrm{mg} P$ per soil $\mathrm{kg}$ were used to obtain different levels of $\mathrm{P}$ availability, and triple superphosphate was used as source. Phosphorus and potassium were incorporated into the soil before sowing. The fertilization with sulfur and micronutrients was made in topdressing at the fifteenth day after seedling emergence.

The soybean cultivars seeds used were W 711; MSoy 7211; Anta 82; TMG 1176; MSoy 7908; TMG 132; Valiosa; MSoy 8766; BRS 271; MSoy 9144; Tracajá; and Candeia. The seeds of each cultivar were treated

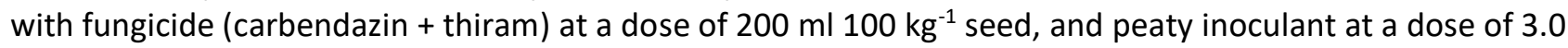
million Bradyrhizobium japonicum bacterium cells per seed. After treatment, they were sown inside plastic pots containing $3.0 \mathrm{dm}^{3}$ sample of a Red Yellow Latossol. Four seeds were sown in each pot for each treatment at a depth of three centimeters and, after emerged, the most vigorous plant was maintained. Irrigation was made with deionized water to keep the water content in the soil with $2 / 3$ of field capacity.

The examined efficiency indexes of P were described by Moll, Kamprath and Jackson (1982) as:

(1) Efficiency in the Use of P (EUSE) - It was obtained by the product between the Efficiency of Absorption $\left(E_{A B S}\right)$ and internal Efficiency of Utilization (EUTLL), corresponding to $\mathrm{kg}$ of grain dry mass (GDM) produced per $\mathrm{kg}$ of $\mathrm{P}$ available on soil (Ps) $\left(\mathrm{kg} \mathrm{kg}^{-1}\right)$;

(2) Efficiency in Response to the Use of Nutrient $\left(E_{R U N}\right)$ - It was obtained by the ratio between the difference of grain yield (DGY) in the two nutrient levels (low and high) and the difference among doses of $P$ on soil (DDPs);

(3) Efficiency of Absorption $\left(E_{A B S}\right)$ - It was obtained by the ratio between the nutrient total amount absorbed by the plant $\left(\mathrm{P}_{\text {тот }}\right)$ and the available $\mathrm{P}$ amount on soil for the plant (Ps), defined as the genotype ability to absorb the available $\mathrm{P}$ on soil, corresponding to $\mathrm{kg}$ of $\mathrm{P}$ in plant per $\mathrm{kg}$ of $\mathrm{P}$ available on soil $(\mathrm{kg} \mathrm{kg}$ $\left.{ }^{1}\right)$;

(4) Efficiency of Utilization (EUTIL - It was obtained by the ratio of grain dry mass (GDM) and the nutrient Agronomy Science and Biotechnology, Rec. 108, Volume 6, Pages 1-11, 2020 
total amount absorbed by the plant $\left(\mathrm{P}_{\text {TOT }}\right)$, defined as the genotype ability for using $\mathrm{P}$ absorbed by the plant for producing grains, corresponding to $\mathrm{kg}$ of grain dry mass produced per $\mathrm{kg}$ of $\mathrm{P}$ in the plant $\left(\mathrm{kg} \mathrm{kg}^{-1}\right)$; and

(5) Quotient of $P$ Utilization (Qutı) is equivalent to "grain dry mass units (GDM) produced per $P$ unit in the grain $\left(P_{\text {grain }}\right) "$ (in $\left.\mathrm{kg} \mathrm{kg}^{-1}\right)$.

The response ratios to the examined P were described by Craswell and Godwin (1984) as:

(1) Efficiency of Apparent Recovery $\left(E_{R E C}\right)$ - It was obtained by the ratio among the difference of the $P$ total amount in the plant and environments with high and low $\mathrm{P}\left(\mathrm{DP}_{\text {Tот }}\right)$ and the difference among the amount of available $P$ on the soil and environments with high and low $P$ on soil $\left(P_{(H-L)}\right)$, defined as genotype's ability to recover the nutrients added to the soil among environments with high and low $\mathrm{P}$, or recovered $\mathrm{kg}$ of $P$ added to the soil among environments;

(2) Physiological Efficiency ( $\left.\mathrm{E}_{\mathrm{PHY}}\right)$ - It was obtained by the ratio among the difference of grain production and high and low $P$ levels $\left(D_{G P}\right)$ for each of the genotypes and the difference of the $P$ total amount in the plant among environments with high and low $\mathrm{P}\left(\mathrm{DP}_{\mathrm{TOT}}\right)$, defined as genotype ability to produce grains per nutrient additional unit in plant among environments with high and low $\mathrm{P}$, or $\mathrm{kg}$ of produced grain per $\mathrm{kg}$ of recovered $\mathrm{P}$ in the plant among environments $\left(\mathrm{kg} \mathrm{kg}^{-1}\right)$;

(3) Agronomic Efficiency $\left(E_{A G R}\right)$ - It was obtained by the product of the apparent recovery efficiency ( $\left.E_{R E C}\right)$ by the physiological efficiency $\left(E_{\mathrm{PHY}}\right)$, and was defined as the genotype ability to produce grain units per fertilizer unit added to soil $\left(\mathrm{kg} \mathrm{kg}^{-1}\right)$;

Cultivar classification on the efficient use and response for $P$ application (efficiency and response - ER) The method proposed by Fageria and Kluthcouski (1980) was used to identify suitable cultivars to environments. The graphic representation was used in the Cartesian plane to classify cultivars. The efficiency for using $P$ is on the $x$-axis; the response to their use is on the ordinate axis. The axes' origin point is the mean efficiency and the cultivars' mean response.

Second stage - Twenty biological samples (freeze-dried leaves) of ten soybean cultivars were analyzed; they were grown in soil with two different doses of P (P1 and P2). Samples were collected between R1 and R2 stages.

For DNA extraction, leaves were collected from each plant under evaluation, packaged in aluminum, and stored in a freezer at $-80{ }^{\circ} \mathrm{C}$. Samples of freeze-dried leaves of soybean accesses were used for DNA extraction. Freeze-dried leaves of each access were used together (bulk) to the first DNA extraction. Another sample of the same access was used to repeat the extraction, enabling Proof test and retest. The extraction was performed in accordance with the protocol described by Ferreira and Grattapaglia (1998). Sixteen selected soybean microsatellite loci were analyzed because they are informative and present a broad experimental validation. Thus, the used microsatellite loci represent a battery of recommended microsatellite markers for soybean genetic analysis, widely used in the literature (Diwan \& Cregan, 1997, Song et al., 1999).

For experimental control of all analyzes, a negative control (water) and a positive control (DNA of soybean line, Genomax (GMX) standard) were used. The used loci were BARC-Satt005 [D1 Connection Group (CG)], BARC-Satt045 (E CG), BARC-Satt038 (G CG), BARC-Satt030 (F CG), BARC-Satt070 (B2 CG ), BARC-Satt100 (C2 CG), BARC-Satt114 (F CG), BARC-Satt181 (H CG), BARC-Satt586 (F CG), S45035 (not available CG), BARCSatt431 (J CG), BARC-Satt216 (D1 CG), GMABAB (N1 CG), BARC-Satt002 (D2 CG), BARC-Satt009 (N1 CG), and BARC-Sat038 (CG).

The loci's polymorphism was analyzed by polymerase chain reaction (PCR), followed by alleles detection, using capillary electrophoresis of high-resolution and automated genotyping in ABI Prism 3100 sequencer. Conditions of allelic amplification by PCR and of genotype analysis by capillary electrophoresis were in accordance with literature specifications (Diwan \& Cregan, 1997; Cregan, Bhagwat, Akkaya, \& Rongwen, 1994). Two DNA extractions and independent genetic analysis of each sample were carried out by different teams in separate days, corresponding to test and counterproof for verification genotypes, minimizing, therefore, the human error possibility.

The allele sizes of each soybean access in the sixteen analyzed microsatellite loci were estimated by the Local Southern algorithm implemented in Genotyper software and then organized into discrete classes of allelic variation, using the algorithm of least squares minimization (Idury \& Cardon, 1997) implemented in Allelobin software.

Genetic similarity values in peer-to-peer comparisons among the analyzed soybean samples were 
estimated based on the ratio among the sum of the common allele proportions and two accesses (Ps) in microsatellite loci and twice the number of tested markers, using the band coefficient (Lynch \& Ho, 2005), implemented in NTSYSpc version $2.10 \mathrm{z}$ program (Rohlf, 2000). The diagonal matrix of genetic similarity was submitted to cluster analysis by Sequential Agglomerative Hierarchical Nested Cluster Analysis (SAHN) procedure, using the Unweighted Pair-Group Method, Arithmetic Average (UPGMA) method; and a dendrogram of genetic similarities was built with the NTSYSpc, version $2.10 z$ program (Rohlf, 2000).

Three similarity matrices were obtained:

(1) Matrix A (similarity among cultivars submitted to the P1 dose of P);

(2) Matrix B (similarity between cultivars submitted to P2 dose of P); and

(3) Matrix C (similarity of cultivars among the P1 and P2 doses of P). Correlation among the matrices was verified by the correlation coefficient among these matrices, which was evaluated at $1 \%$ probability by Mantel's test (10,000 simulations) and by the t-test. This analysis was performed based on Genes Program (Cruz, 2013).

The experiment in greenhouse was performed under experimental design of randomized blocks with five replicates in $2 \times 12$ factorial scheme, which corresponds to two doses of P on soil (P1 and P2) and twelve soybean cultivars, totaling twenty-four treatments. Data were subjected to analysis of variance and means of qualitative factors were compared using the F test $(p<0.05)$ for doses (P1 and P2) of P on soil and the Tukey test $(p=0.05)$ for cultivars.

\section{RESULTS AND DISCUSSION}

There was a significant effect on all the analyzed factors for both cultivars and P doses added to the soil as well as for the interaction. It was found wide variability among the materials, and the performance evaluation of each cultivar depended on the characteristic under analysis.

Using the lowest dose of $P(P 1)$, in the case of the cultivars' average, the increases in efficiency of $P$ use (EUSE), the efficiency of absorption ( $\left.E_{A B S}\right)$, the efficiency of utilization ( $\left.E_{U T L L}\right)$, and the quotient of $P$ utilization (QuTIL) were 113, 4, 93, and $67 \%$, respectively, compared to larger dose of $\mathrm{P}$ on soil (P2), a behavior contrary to what happened with the growth and yield components (Table 1). The efficiency values usually decrease with increased nutrient levels due to the high leveling of production with increasing content at the same level (Fageria, 1992); this fact means, for example, that the efficiency of $P$ utilization is the maximum at the lowest nutrient level and minimum at the highest nutrient level. This fact has been observed in many studies (Machado \& Furlani, 2004; Gill, Salim, \& Zia, 1992).

Valiosa cultivar showed higher efficiency of P use (EusE) at P1 and P2 dose of P on the soil; and it was 169 $\%$ higher than the Anta 82 cultivar in P1 dose, which showed a lower value. Tracajá and Candeia cultivars showed the highest efficiency of absorption $\left(E_{A B S}\right)$ at the lowest $P 1$ dose and the highest $P 2$ dose of $P$ on soil, respectively. The W711 cultivar showed the highest efficiency of utilization (EUTIL) in the P2 dose of $P$ on soil, while the Valiosa cultivar showed the same performance for P1 dose of P on soil. In the P2 dose of P on soil, TMG 132 cultivar showed the largest quotient of $P$ utilization (QuTIL) and MSoy 7908 cultivar showed the same performance for the P1 dose of P on soil (Table 1).

The efficiency indexes are important tools for determining the nutritional performance in plants. Based on them, it is possible to view characteristics of nutrient absorption and of plant yield together (FritscheNeto \& Borém, 2012).

Besides the efficiency indexes of used $P$, its response rates were also determined, which are efficiency of apparent recovery $\left(E_{R E C}\right)$, agronomic efficiency $\left(E_{A G R}\right)$, physiological efficiency $\left(E_{P H Y}\right)$, and efficiency of response to the use of $P\left(E_{R U N}\right)$. The highest values of $E_{R E C}$ and $E_{P H Y}$ were obtained with the Candeia and W711 cultivars, respectively, which were 304 and $253 \%$, rates higher than for the worst cultivars. The TMG 132 cultivar showed the highest $E_{A G R}$ and $E_{R U N}$, with increases of 220 and $110 \%$, respectively (Table 2).

For genotype classification on the efficiency of nutrients by plants, it is important to consider the factors that affect the ability and those ones effective in the discrimination of existing genetic differences. Once these differences are observed and reported as variability, tools are created for using the plant genetic improvement. 
Table 1. Efficiency of using phosphorus ( $\left.E_{\mathrm{USE}}\right)$, efficiency of absorption $\left(\mathrm{E}_{\mathrm{ABS}}\right.$ ), efficiency of utilization ( $\left.\mathrm{E}_{\mathrm{UTIL}}\right)$ and quotient of phosphorus utilization (Qutı) due to the phosphorus doses added to soil (P1 and P2).

\begin{tabular}{|c|c|c|c|c|}
\hline \multirow{3}{*}{ Cultivars } & \multicolumn{2}{|c|}{ EUSE $_{\text {US }}$} & \multicolumn{2}{|c|}{$E_{A B S}$} \\
\hline & \multicolumn{2}{|c|}{$\left(\mathrm{kg} \mathrm{kg}^{-1}\right)$} & \multicolumn{2}{|c|}{$\left(\mathrm{kg} \mathrm{kg}^{-1}\right)$} \\
\hline & P1 & $\mathrm{P} 2$ & P1 & P2 \\
\hline W 711 & $429.30 \mathrm{CDa}$ & $213.70 \mathrm{Ab}$ & $11.79 \mathrm{ABa}$ & $7.04 \mathrm{Ea}$ \\
\hline MSoy 7211 & 548.91 BCDa & $241.27 \mathrm{Ab}$ & $13.42 \mathrm{ABa}$ & 10.03 DEa \\
\hline ANTA 82 & 326.89 Da & $143.19 \mathrm{Ab}$ & $10.01 \mathrm{Ba}$ & $6.27 \mathrm{Ea}$ \\
\hline TMG 1176 & 569.03B CDa & $268.34 \mathrm{Ab}$ & $12.68 \mathrm{ABa}$ & 10.94 CDEa \\
\hline MSoy 7908 & $828.85 \mathrm{ABa}$ & $305.79 \mathrm{Ab}$ & $15.84 \mathrm{ABa}$ & 14.26 ABCDa \\
\hline TMG 132 & 570.05B CDa & $421.22 \mathrm{Aa}$ & $12.74 \mathrm{ABa}$ & 18.68 ABCDb \\
\hline Valiosa & $880.40 \mathrm{Aa}$ & $433.18 \mathrm{Ab}$ & $19.02 \mathrm{ABa}$ & 19.16 ABCa \\
\hline MSoy 8766 & 7218.7 ABCa & 409.47 Ab & $15.92 \mathrm{ABa}$ & $20.28 \mathrm{ABa}$ \\
\hline BRS 271 & 563.57 BCDa & $313.10 \mathrm{Ab}$ & $15.69 \mathrm{ABa}$ & 17.05 ABCDa \\
\hline MSoy 9144 & $828.52 \mathrm{ABa}$ & $428.43 \mathrm{Ab}$ & $18.52 \mathrm{ABa}$ & 19.74 ABCa \\
\hline Tracajá & 814.96 ABa & $228.16 \mathrm{Ab}$ & $20.40 \mathrm{Aa}$ & 11.46 BCDEb \\
\hline Candeia & 747.93 ABa & $267.62 \mathrm{Ab}$ & $19.10 \mathrm{ABa}$ & $22.79 \mathrm{Aa}$ \\
\hline Mean & 652.52 & 306.12 & 15.43 & 14.81 \\
\hline \multirow[t]{2}{*}{ C. V. } & \multicolumn{2}{|c|}{13.64} & \multicolumn{2}{|c|}{15.42} \\
\hline & & & & \\
\hline \multirow[t]{2}{*}{ Cultivars } & \multicolumn{2}{|c|}{$\left(\mathrm{kg} \mathrm{kg}^{-1}\right)$} & \multicolumn{2}{|c|}{$\left(\mathrm{kg} \mathrm{kg}^{-1}\right)$} \\
\hline & P1 & P2 & P1 & P2 \\
\hline W 711 & $36.64 \mathrm{BCa}$ & $29.79 A b$ & $241.45 \mathrm{Ea}$ & $208.64 \mathrm{Ab}$ \\
\hline MSoy 7211 & $41.25 \mathrm{ABCa}$ & $24.21 \mathrm{ABb}$ & 333.35 CDa & $201.37 \mathrm{Ab}$ \\
\hline ANTA 82 & $33.57 \mathrm{Ca}$ & $23.17 \mathrm{ABb}$ & 232.92 Ea & $195.60 \mathrm{Ab}$ \\
\hline TMG 1176 & $45.43 \mathrm{ABa}$ & $24.69 \mathrm{ABb}$ & 365.52 BCDa & $223.28 \mathrm{Ab}$ \\
\hline MSoy 7908 & $52.17 \mathrm{Aa}$ & $22.15 \mathrm{ABCb}$ & 419.26 Aa & $221.38 \mathrm{Ab}$ \\
\hline TMG 132 & $45.17 \mathrm{ABa}$ & $23.00 \mathrm{ABb}$ & $397.65 \mathrm{ABa}$ & $229.34 \mathrm{Ab}$ \\
\hline Valiosa & $46.51 \mathrm{ABa}$ & $22.67 \mathrm{ABb}$ & 385.13 ABCa & $221.20 \mathrm{Ab}$ \\
\hline MSoy 8766 & $45.05 \mathrm{ABa}$ & $20.48 \mathrm{ABCb}$ & $392.05 \mathrm{ABa}$ & $213.33 \mathrm{Ab}$ \\
\hline BRS 271 & $36.12 \mathrm{BCa}$ & $18.38 \mathrm{BCb}$ & 321.38 Da & $220.58 \mathrm{Ab}$ \\
\hline MSoy 9144 & $44.88 \mathrm{ABa}$ & $21.95 \mathrm{ABCb}$ & 390.07 ABa & $212.38 \mathrm{Ab}$ \\
\hline Tracajá & $40.99 \mathrm{BCa}$ & $20.54 \mathrm{ABCb}$ & 379.08 ABCa & $212.96 \mathrm{Ab}$ \\
\hline Candeia & 39.38 BCa & $11.65 \mathrm{Cb}$ & $412.13 \mathrm{ABa}$ & $203.68 \mathrm{Ab}$ \\
\hline Mean & 42.26 & 21.89 & 355.83 & 213.64 \\
\hline C. V. & & & & \\
\hline
\end{tabular}

P1 (30 mg kg-1 of P on soil); P2 (300 $\mathrm{mg} \mathrm{kg}^{-1}$ of P on soil). Inside each P dose, the means followed by the same lowercase on the line and uppercase in the column do not differ by $F$ test $(p<0.05)$ and Tukey test $(p=0.05)$, respectively. 
Table 2. Efficiency of Apparent Recovery $\left(E_{R E C}\right)$, physiological efficiency $\left(E_{P H Y}\right)$ agronomic efficiency $\left(E_{A G R}\right)$, and response efficiency for the phosphorus utilization $\left(E_{R U N}\right)$ due to the phosphorus dose added to soil (P1 and P2).

\begin{tabular}{lcccc}
\hline \multirow{2}{*}{ Cultivars } & $\mathrm{E}_{\mathrm{REC}}$ & $\mathrm{E}_{\mathrm{PHY}}$ & $\mathrm{E}_{\mathrm{AGR}}$ & $\mathrm{E}_{\mathrm{RUN}}$ \\
\cline { 2 - 5 } & $\left(\mathrm{kg} \mathrm{kg}^{-1}\right)$ & $\left(\mathrm{kg} \mathrm{kg}^{-1}\right)$ & $\left(\mathrm{kg} \mathrm{kg}^{-1}\right)$ & $\left(\mathrm{kg} \mathrm{kg}^{-1}\right)$ \\
\hline W 711 & $6.59 \mathrm{D}$ & $28.30 \mathrm{~A}$ & $192.36 \mathrm{D}$ & $16.72 \mathrm{ABC}$ \\
MSoy 7211 & $9.69 \mathrm{CD}$ & $21.65 \mathrm{AB}$ & $209.14 \mathrm{BCD}$ & $16.70 \mathrm{ABC}$ \\
ANTA 82 & $5.89 \mathrm{D}$ & $21.28 \mathrm{AB}$ & $122.74 \mathrm{D}$ & $12.41 \mathrm{CD}$ \\
TMG 1176 & $11.04 \mathrm{BCD}$ & $21.44 \mathrm{AB}$ & $234.42 \mathrm{ABCD}$ & $18.03 \mathrm{AB}$ \\
MSoy 7908 & $14.13 \mathrm{ABCD}$ & $17.57 \mathrm{~B}$ & $236.66 \mathrm{ABCD}$ & $15.10 \mathrm{BC}$ \\
TMG 132 & $20.35 \mathrm{AB}$ & $19.89 \mathrm{AB}$ & $392.79 \mathrm{~A}$ & $20.65 \mathrm{~A}$ \\
Valiosa & $19.53 \mathrm{ABC}$ & $18.99 \mathrm{~B}$ & $368.74 \mathrm{AB}$ & $17.40 \mathrm{ABC}$ \\
MSoy 8766 & $21.24 \mathrm{AB}$ & $17.39 \mathrm{~B}$ & $361.43 \mathrm{ABC}$ & $17.00 \mathrm{ABC}$ \\
BRS 271 & $17.35 \mathrm{ABC}$ & $15.88 \mathrm{BC}$ & $275.67 \mathrm{ABCD}$ & $17.94 \mathrm{AB}$ \\
MSoy 9144 & $20.26 \mathrm{AB}$ & $18.52 \mathrm{~B}$ & $369.14 \mathrm{AB}$ & $17.16 \mathrm{ABC}$ \\
Tracajá & $10.87 \mathrm{BCD}$ & $17.86 \mathrm{~B}$ & $182.75 \mathrm{D}$ & $15.60 \mathrm{BC}$ \\
Candeia & $23.82 \mathrm{~A}$ & $8.02 \mathrm{C}$ & $197.23 \mathrm{CD}$ & $9.83 \mathrm{D}$ \\
\hline \multicolumn{1}{c}{ Mean } & 15.06 & 18.90 & 261.92 & 16.21 \\
\hline C. V & 13.97 & 12.61 & 13.47 & 14.25 \\
\hline
\end{tabular}

The means followed by the same capital letter in the column do not differ from each other by Tukey test $(p=0.05)$

The $P$ efficiency may come from the efficiency of absorption and/or utilization of $P$ (Föhse, Claassen, \& Jungk, 1988). In this work, it was observed that both the efficiency of $P$ utilization and the efficiency of $P$ absorption exhibited differences among the soybean cultivars.

Along with the work on efficiency of nutrients by plants, studies on methods of selection and discrimination materials, applied in breeding programs, proposed the discussion on the response to fertilization (Fageria \& Kluthcouski, 1980). The response to fertilization according to Araújo (2000) is associated with the capacity increase of biomass production with higher nutrient supply.

Plant genotype classification in terms of efficiency to use a certain nutrient and response to treatment can be carried out using graphic representation in the Cartesian plane (Fageria \& Kluthcouski, 1980). These authors have considered the nutrient utilization as productivity at low level and response to $P$ application in accordance with Fox (1978). This methodology was applied to this work. The point of the axes' origin is the average efficiency and the mean response of the cultivars. The efficiency of $P$ utilization is on the $x$-axis; the response to its use is on the ordinate axis. Thus, the efficiency of nutrient utilization is defined by the average grain yield in low nutrient level (P1 dose of $\mathrm{P}$ on soil), and the response to its utilization was obtained by the difference between the grain yield in both nutrient levels divided by the difference among the levels of $P$ doses on soil. This methodology was appropriate because field tests are part of breeding programs routine and they have proven effective in greenhouse conditions.

The average production of twelve cultivars at low $\mathrm{P}$ level and the efficiency average of twelve cultivars in $\mathrm{P}$ utilization were used as cultivar separation indexes and were classified into four groups (Figure 1):

(1) Efficient and Responsive (ER) group, comprising TMG 1176, TMG 132, Valiosa, and MSoy 9144;

(2) Not Efficient and Responsive (NER) group, comprising W 711, MSoy 7211, MSoy 8766, and BRS 271 cultivars;

(3) Not Effective and Not Responsive (NENR) group, comprising Anta 82 and Tracajá cultivars; and

(4) Efficient and Not Responsive (ENR) group, comprising MSoy 7211 and Candeia cultivars.

Under a practical standpoint, the genotypes that produced very low levels of $\mathrm{P}$ and responded well to the $P$ application are considered the best. The genotypes of high efficiency of $P$ utilization and low Agronomy Science and Biotechnology, Rec. 108, Volume 6, Pages 1-11, 2020 
responsiveness should be prioritized in breeding programs to better $\mathrm{P}$ utilization under low level of this nutrient. As a result, more attention should be given to genotypes classified as ENR. However, attention should be paid to genotypes classified as ER, when the intention is to select plants with good performance in environments with $P$ restriction and that also could respond to the application.

Cultivars that stood out due to their distance from the origin point (in Cartesian graph) are TMG 132, Candeia, and Anta 82. This differentiated and contrasting behavior can be used in studies for the mechanism characterization that provide efficiency, response, not efficiency, or not response of utilization as well as of the $\mathrm{P}$ absorption. In addition, these results should be tested under field conditions for validation.

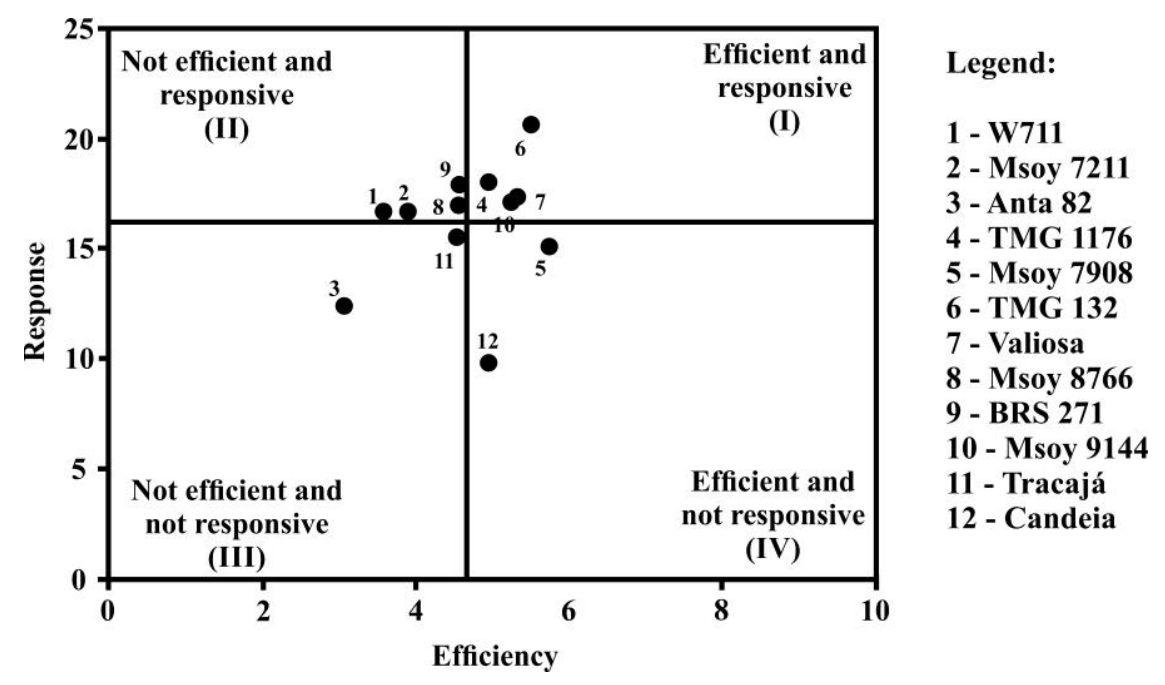

Figure 1. Classification of soybean cultivars for efficiency of $P$ utilization and response to fertilization, according to Fageria and Kluthcouski (1980) methodology.

The genetic similarity of the same cultivar when subjected to two $\mathrm{P}$ doses was high, i.e., it ranged from 0.94 (BRS 271, MSOY 7908, Valiosa, and Anta 82 cultivars) to 1.00 (W 711, TMG 132, MSOY 8766, MSOY 9144, and TMG 1176 cultivars) (Figure 2).

However, with the same simple sequence repeat (SSR) loci, it was possible to identify wide genetic diversity among cultivars; and W 711 had the lowest similarity with all others (band coefficient $=0.18$ ), while MSOY 7908 and Valiosa cultivars were the most similar (0.75). Soybean is an autogamous and diploid species; genotypes observed in each locus are typically homozygous, i.e., only a duplicate allele is observed at each locus. Occasionally, two separate alleles can be seen, evidencing residual heterozygosity, in the case of analysis of individual plants. The bulk analysis of collected freeze-dried leaves does not allow discriminating these possibilities, and specific tests can be used for this purpose. Alleles are displayed as peaks after capillary electrophoresis and high resolution; and they are identified in base pairs for automatic comparison with an internal standard of known size DNA fragments in automated DNA sequencer.

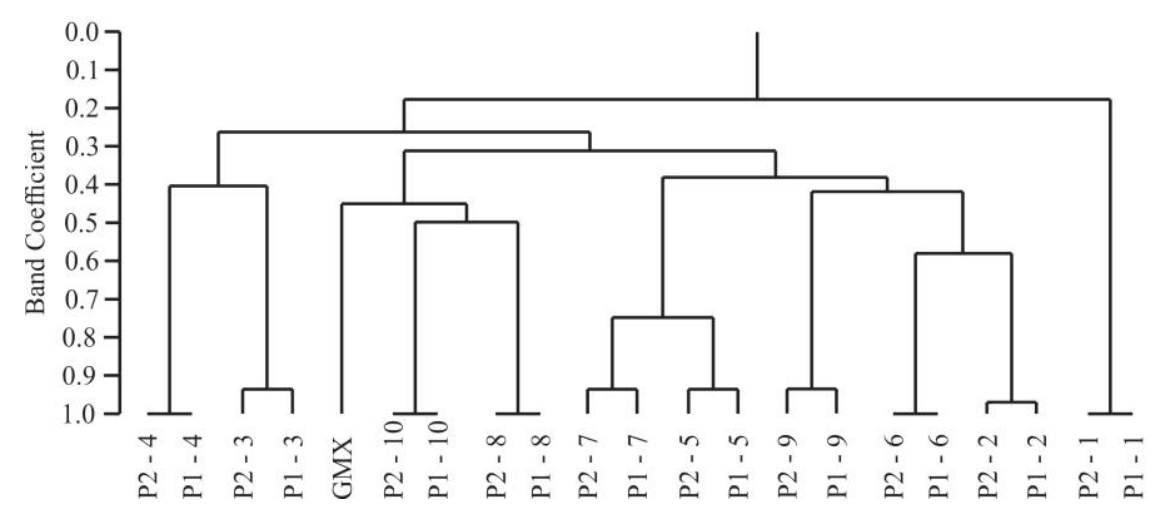

$$
\begin{aligned}
& \text { Legend: } \\
& \text { P1 - Dose } 1 \text { of phosphorus } \\
& \text { P2 - Dose } 1 \text { of phosphorus } \\
& \text { 1 - W711 } \\
& 2 \text { - Msoy } 7211 \\
& 3 \text { - Anta } 82 \\
& 4 \text { - TMG } 1176 \\
& \text { 5 - Msoy } 7908 \\
& 6 \text { - TMG } 132 \\
& 7 \text { - Valiosa } \\
& \text { 8 - Msoy } 8766 \\
& 9 \text { - BRS } 271 \\
& 10 \text { - Msoy } 9144 \\
& 11 \text { - Tracajá } \\
& 12 \text { - Candeia }
\end{aligned}
$$

Figure 2. Representation of the genetic link relationship among soybean samples based on peer-to-peer genetic distance estimates, concluded by the proportion of common alleles (band coefficient), subjected to cluster analysis by UPGMA method. "GMX" Soybean sample (standard) was also included in the 
The first study to characterize the genetic basis of soybean cultivars in Brazil was carried out by Hiromoto and Vello (1986). These authors reported a narrow genetic variability of soybean and the need to increase the genetic basis of Brazilian cultivars, aiming to avoid the danger of germplasm genetic vulnerability and the establishment of production baseline. Furthermore, a study by Oda et al. (2015) indicated that the genetic variability has remained the same over the almost 40 years of soybean breeding, considering the phenotypic and molecular characters (SSR markers) and the relationship coefficient.

Silva et al. (2017) reported that genetic variability between cultivars from agromorphological characters depends on the growing season, and molecular marker showed that the genetic variability among studied cultivars and formed clusters were different from those obtained with agronomic trait. So, these authors concluded that both phenotypic and molecular data proved to be informative tools to characterize existing variability between soybean cultivars. In this study, with used SSR, it was not possible to detect the existence of genetic variability of the same cultivar when subjected to different $\mathrm{P}$ doses on soil. However, the existence of genetic variability among cultivars was clearly identified, excluding the effect of $P$ levels on soil.

The correlation coefficients obtained was 0.9635 for Matrix A vs Matrix B, 0.9783 for Matrix A vs Matrix C, and 0.9695 for Matrix B vs Matrix C, whereas Matrix A (similarity among cultivars submitted to the P1 dose of $\mathrm{P}$ ); Matrix B (similarity among cultivars submitted to P2 dose of P); and Matrix C (similarity of cultivars among the $\mathrm{P} 1$ and $\mathrm{P} 2$ doses of $\mathrm{P}$ ). All of correlation coefficients were significant at $1 \%$ probability by the $\mathrm{t}$ test; and at $1 \%$ probability of Mantel's test based on 10,000 simulations.

According to Rohlf (2000), correlation values lower than 0.7 have been considered inconsistent, indicating that the obtained genetic diversity based on a character set does not explain the diversity based on another set. Consistent correlation values were obtained for the combinations of possible matrices, i.e., 0.96 above. The high correlation among the matrices confirms the information presented in the dendrogram as the similarity among cultivars submitted to different $P$ doses on soil. When analyzing together the obtained information for phenotypic and molecular diversity, TMG 1176 x MSOY 9144, TMG 1176 x Valiosa, and TMG $1176 \times$ TMG 132 hybrid combinations are identified as the ones of greatest potential for the population development with efficient genotypes in $\mathrm{P}$ use, responsive for the $\mathrm{P}$ increase with genetic diversity.

\section{CONCLUSIONS}

The efficient genotypes in $\mathrm{P}$ utilization and responsive to $\mathrm{P}$ increment through specific methodology for mineral stress were TMG 1176, TMG 132, Valiosa, and MSoy 9144; and the used microsatellite loci were efficient for detecting, in general, the genetic variability among cultivars, but they were not efficient to differentiate cultivars cultivated in two different environments of phosphorus on soil.

\section{ACKNOWLEDGEMENTS}

Thanks to Conselho Nacional de Desenvolvimento Científico e Tecnológico (CNPq) (National Counsel of Technological and Scientific Development) of Brazil, for granting post-doctoral fellowship; and to the Federal University of Viçosa; and to the teachers Sediyama, Tuneo; and Neves, César Lima, advisor and coadvisor, respectively.

\section{REFERENCES}

Araújo, A. P. (2000). Eficiência vegetal de absorção e utilização de fósforo, com especial referência ao feijoeiro. In C. E. G. R. Novais, R.F., Alvarez, V., V.H., Schaefer (Ed.), Tópicos em ciência do solo. Sociedade Brasileira de Ciência do Solo. Retrieved from https://www.scielo.br/scielo.php?script=sci_nlinks\&ref=000080\&pid=S0006$8705200500040001400001 \&$ lng $=$ pt

Bernardeli, A., Borem, A., Lorenzoni, R., Aguiar, R., Nayara, J., Silva, B., ... Costa, M. D. L. (2020). SNP marker association for incrementing soybean seed protein content. Agronomy Science and Biotechnology, 6(2015), 1-11. https://doi.org/10.33158/ASB.r107.v6.2020 
Bortolotto, O. C., Pomari-Fernandes, A., Bueno, R. C. O. de F., Bueno, A. F., Cruz, Y. K. S., Sanzovo, A., \& Ferreira, R. B. (2015). The use of soybean integrated pest management in Brazil: a review. Agronomy Science and Biotechnology, 1(1), 25. https://doi.org/10.33158/asb.2015v1i1p25

Camargos, T., Campos, N., Alves, G., Ferreira, S., \& Matsuo, É. (2019). The effect of soil volume, plant density and sowing depth on soybean seedlings characters. Agronomy Science and Biotechnology, 5(2), 47. https://doi.org/10.33158/asb.2019v5i2p47

Clarkson, D. T., Hawkesford, M. j. (1993). Molecular biological approaches to plant nutrition. Plant and Soil, 155/156, 21-31. Retrieved from https://www.jstor.org/stable/42939259?seq=1

Craswell, E. T., Godwin, D. C. (1984). The efficiency of nitrogen fertilizers applied to cereals growing in different climates. Advances in Plant Nutrition, 1, 1-55. Retrieved from https://books.google.com.br/books/about/Advances_in_Plant_Nutrition.html?id=nl7HAAAACAAJ\&redir _esc=y

Cregan, P. B., Bhagwat, A .A., Akkaya, M. S., Rongwen, J. (1994). ) Microsatellite fingerprinting and mapping of soybean. Methods in Molecular and Cellular Biology, 5, 49-61. Retrieved from https://www.ars.usda.gov/ARSUserFiles/1190/cregan94.pdf

Cruz, C. D. (2013). GENES - Software para análise de dados em estatística experimental e em genética quantitativa. Acta Scientiarum - Agronomy, 35(3), 271-276. https://doi.org/10.4025/actasciagron.v35i3.21251

Diwan, N., \& Cregan, P. B. (1997). Automated sizing of fluorescent-labeled simple sequence repeat (SSR) markers to assay genetic variation in soybean. TAG Theoretical and Applied Genetics, 95(5-6), 723-733. doi:10.1007/s00. TAG Theoretical and Applied Genetics, 95(5-6), 723-733. https://doi.org/10.1007/s001220050618

Fageria, N.D., Kluthcouski, J. (1980). Metodologia para avaliação das cultivares de arroz e feijão, para condições adversas de solo. Goiania: Embrapa-CNPAF, 21. Retrieved from https://ainfo.cnptia.embrapa.br/digital/bitstream/CNPAF/1832/1/circ_8.pdf

Fageria, N. K. (1992). Maximizing crop yields. New York: Marcel Dekker. Retrieved from https://www.cabdirect.org/cabdirect/abstract/19920755740

Ferreira, M. E., Grattapaglia, D. (1998). Introducao ao uso de marcadores moleculares em analise genetica (3rd ed.). Brasilia: Embrapa Recursos Genéticos e Biotecnologia https://livimagens.sct.embrapa.br/amostras/00063810.pdf

Föhse, D., Claassen, N., \& Jungk, A. (1988). Phosphorus efficiency of plants - I. External and internal P requirement and $P$ uptake efficiency of different plant species. Plant and Soil, 110(1), 101-109. https://doi.org/10.1007/BF02143545

Fox, R. H. (1978). Selection for phosphorus efficiency in corn. Communications in Soil Science and Plant Analysis, 9(1), 13-37. https://doi.org/10.1080/00103627809366784

Fritsche-Neto, R. Borém, A. (2012). Plant Breeding for Abiotic Stress Tolerance. Berlin, Heidelberg: Springer. https://doi.org/DOI https://doi.org/10.1007/978-3-642-30553-5

Fu, Y. B., Peterson, G. W., \& Morrison, M. J. (2007). Genetic diversity of Canadian soybean cultivars and exotic germplasm revealed by simple sequence repeat markers. Crop Science, 47(5), 1947-1954. https://doi.org/10.2135/cropsci2006.12.0843

Gill, M. A., Salim, M., \& Zia, M. S. (1992). Maize growth and uptake of phosphate and copper at different ambient phosphate concentrations. Soil Science and Plant Nutrition, 38(4), 631-636. https://doi.org/10.1080/00380768.1992.10416692 
Harada, A., Gonçalves, L. S. A., Kiihl, R. A. S., \& Destro, D. (2015). Flowering under short days: juvenile period and inductive phase estimates in soybean genotypes. Agronomy Science and Biotechnology, 1(1), 10. https://doi.org/10.33158/asb.2015v1i1p10

Hiromoto, D. M.; Vello, N. A. (1986). The genetic base of Brazilian soybean (Glycine max (L.) Merrill) cultivars. Revista Brasileira de Genética, 9, 295-906.

Hwang, T. Y., Gwak, B. S., Sung, J., \& Kim, H. S. (2020). Genetic diversity patterns and discrimination of 172 korean soybean (Glycine max (L.) merrill) varieties based on SSR analysis. Agriculture (Switzerland), 10(3). https://doi.org/10.3390/agriculture10030077

Idury, R. M., \& Cardon, L. R. (1997). A Simple Method for Automated Allele Binning in Microsatellite Markers. Genome Research, 7(11), 1104-1109. https://doi.org/10.1101/gr.7.11.1104

Kujane, K., Sedibe, M. M., \& Mofokeng, A. (2019). Genetic diversity analysis of soybean (Glycine max (L.) Merr.) genotypes making use of SSR markers. Australian Journal of Crop Science, 13(7), 1113-1119. https://doi.org/10.21475/ajcs.19.13.07.p1638

Lambers, H., Shane, M. W., Cramer, M. D., Pearse, S. J., \& Veneklaas, E. J. (2006). Root structure and functioning for efficient acquisition of phosphorus: Matching morphological and physiological traits. Annals of Botany, 98(4), 693-713. https://doi.org/10.1093/aob/mcl114

Lynch, J. P., \& Ho, M. D. (2005). Rhizoeconomics: Carbon costs of phosphorus acquisition. Plant and Soil, 269(1-2), 45-56. https://doi.org/10.1007/s11104-004-1096-4

Machado, C. T. T., \& Furlani, Â. M. C. (2004). Kinetics of phosphorus uptake and root morphology of local and improved varieties of maize. Scientia Agricola, 61(1), 69-76. https://doi.org/10.1590/s010390162004000100012

Moll, R. H., Kamprath, E. J., \& Jackson, W. A. (1982). Analysis and Interpretation of Factors Which Contribute to Efficiency of Nitrogen Utilization 1. Agronomy Journal, 74(3), 562-564. https://doi.org/10.2134/agronj1982.00021962007400030037x

Novais, R.F., \& Smyth, T.J. (1999) Fósforo em solo e planta em condições tropicais. Viçosa: Editora UFV. http://www.ipni.net/publication/ia-brasil.nsf/0/241DADE2FCFB2F1783257B8D004C15FF/\$FILE/page1011-87.pdf

Oda, M. D. C., Sediyama, T., Matsuo, É., Cruz, C. D., Barros, E. G, \& Ferreira, M. F. S. (2015). Phenotypic and molecular traits diversity in soybean launched in forty years of genetic breeding. Agronomy Science and Biotechnology, 1(1), 1-9. https://doi.org/10.33158/asb.2015v1i1p1

Oliveira, D., Furmigare, N. S., \& Peluzio, J. M. (2019). Divergência genética em linhagens de soja visando a produção de biodiesel no Estado do Tocantins. Magistra, 30, 113-122. Retrieved from https://magistraonline.ufrb.edu.br/index.php/magistra/article/view/642

Rausch, C., \& Bucher, M. (2002). Molecular mechanisms of phosphate transport in plants. Planta, 216(1), 23-37. https://doi.org/10.1007/s00425-002-0921-3

Rohlf, F. J. (2000). NTSYSpc: numerical taxonomy and multivariate analysis system. New York: Exeter Software. https://www.scienceopen.com/document?vid=8071739f-efd0-4990-9970-47e831f11f8b

Sahrawat, K. L., \& Sika, M. (2002). Direct and residual phosphorus effects on soil test values and their relationships with grain yield and phosphorus uptake of upland rice on an ultisol. Communications in Soil Science and Plant Analysis, 33(3-4), 321-332. https://doi.org/10.1081/CSS-120002748 
Samanfar, B., Cober, E. R., Charette, M., Tan, L. H., Bekele, W. A., Morrison, M. J., ... Molnar, S. J. (2019). Genetic Analysis of High Protein Content in 'AC Proteus' Related Soybean Populations Using SSR, SNP, DArT and DArTseq Markers. Scientific Reports, 9(1), 1-10. https://doi.org/10.1038/s41598-019-55862-9

Shenoy, V. V., \& Kalagudi, G. M. (2005). Enhancing plant phosphorus use efficiency for sustainable cropping. Biotechnology Advances, 23(7-8), 501-513. https://doi.org/10.1016/j.biotechadv.2005.01.004

Silva, A. F., Sediyama, T., Matsuo, É., Silva, F. C. S., Cruz, C. D., Borém, A., \& Bezerra, A. R. G. (2017). Phenotypic and molecular diversity among soybean cultivars as a function of growing season. Agronomy Science and Biotechnology, 1(2), 52-61. https://doi.org/10.33158/ASB.2015v1i2p52

Soares, M. M., Silva, L. J., Oliveira, G. L., Sekita, M. C., \& Dias, D. C. F. S. (2014). Endogenous level of phosphorous in soya bean seeds and the relationship with physiological quality, oil and protein content. Seed Science and Technology, 42(3), 433-443. https://doi.org/10.15258/sst.2014.42.3.09

Song, Q. J., Quigley, C. V., Nelson, R. L., Carter, T. E., Boerma, H. R., Strachan, J. L., \& Cregan, P. B. (1999). A selected set of trinucleotide simple sequence repeat markers for soybean cultivar identification. Plant Varieties and Seeds, 12(3), 207-220. Retrieved from https://experts.illinois.edu/en/publications/aselected-set-of-trinucleotide-simple-sequence-repeat-markers-fo

Wang, L., Guan, R., Zhangxiong, L., Chang, R., \& Qiu, L. (2006). Genetic diversity of Chinese cultivated soybean revealed by SSR markers. Crop Science, 46(3), 1032-1038. https://doi.org/10.2135/cropsci2005.0051

Yang, Y., Tong, Y., Li, X., He, Y., Xu, R., Liu, D., ... Liao, H. (2019). Genetic analysis and fine mapping of phosphorus efficiency locus 1 (PE1) in soybean. Theoretical and Applied Genetics, 132(10), 2847-2858. https://doi.org/10.1007/s00122-019-03392-3

Yang, Y., Wang, L., Zhang, D., Cheng, H., Wang, Q., Yang, H., \& Yu, D. (2020). GWAS identifies two novel loci for photosynthetic traits related to phosphorus efficiency in soybean. Molecular Breeding, 40(3). https://doi.org/10.1007/s11032-020-01112-0

Received: June 1, 2020,

Accepted: July 21, 2020,

Published: July 31, 2020.

\section{English by: Marcos Morais Soares.}

